\title{
3.6\%-CZTSS Device Fabricated From Ionic Liquid Electrodeposited Sn Layer
}

\author{
Raghu N. Bhattacharya*
}

National Renewable Energy Laboratory, 1617 Cole Boulevard, Golden, Colorado 80401, USA

\begin{abstract}
Cu} / \mathrm{Sn} / \mathrm{Zn}$ stacked layers were electrodeposited and subsequently annealed in a tube furnace in elemental sulfur and selenium at $570^{\circ} \mathrm{C}$. Cyclic voltammogram of Sn-salt in ionic liquid was recorded. Thin films were characterized by inductively coupled plasma-mass spectrometry (ICP-MS), Auger electron spectroscopy (AES) and scanning electron microscopy (SEM). The device was characterized by current-voltage (I-V) and quantum efficiency (QE). The device fabricated using electrodeposited precursor film resulted in efficiencies of $3.6 \%$.
\end{abstract}

Keywords: $\mathrm{Cu}-\mathrm{Zn}-\mathrm{Sn}-\mathrm{S}-\mathrm{Se}, \mathrm{Cu} / \mathrm{Sn} / \mathrm{Zn}$ stacked layer, ionic liquid, electrodeposited.

\section{INTRODUCTION}

Photovoltaic (PV) solar electric technology will be a significant contributor to world energy supplies when reliable, efficient PV power products are manufactured in large volumes at low cost. A promising pathway to reduce PV cost is the use of thin-film technologies in which thin layers of photoactive materials are deposited inexpensively on large-area substrates. The primary chalcogenide semiconductor absorber materials currently used for thinfilm PV device applications are $\mathrm{Cu}(\mathrm{In}, \mathrm{Ga}) \mathrm{Se}_{2}$ and $\mathrm{CdTe}$. Despite the promise of these technologies, the toxicity of $\mathrm{Cd}$ and supply limitations for In and Te are projected to limit the production capacity of these existing chalcogen-based technologies to $<100 \mathrm{GWp}$ per year. This represents a small fraction of the world's growing energy needs, which are expected to double to $27 \mathrm{TW}$ by 2050 . Therefore, a lot of efforts have been made recently to explore new absorber materials with nontoxic and earth-abundant elements. One prominent example of the alternative solar cell materials is $\mathrm{Cu}_{2} \mathrm{ZnSn}(\mathrm{SSe})_{4}$ (CZTSS). CZTSS has a direct band gap of $1.45-1.6 \mathrm{eV}$ and an optical absorption coefficient of around $10^{5} \mathrm{~cm}^{-1}[1,2]$. Recently several groups reported CZTSS thin-films prepared by variety of fabrication methods, namely sputtering [2-5], physical vapor deposition [6-11], solution-particle approach [12-14], photochemical deposition [15], sol-gel method [16], screen-printing [17], and electroplating [18-26]. The best conversion efficiency of the CZTS solar cell is reported to be $11.1 \%$ using ink-based solution-particle approach [27]. The electroplated CZTS solar cell also demonstrated a respectable 7.3\%-efficient device [26].

Electroplating is a potentially suitable preparation method to obtain low-cost precursor films. The electrodeposition process could provide: (a) high-quality film with very low capital investment; (b) a low-cost, high-rate process;

*Address correspondence to this author at the National Renewable Energy Laboratory, 1617 Cole Boulevard, Golden Colorado 80401, USA;

Tel: 303-384-6477; Fax: 303-384-6430;

E-mail: Raghu.Bhattacharya@nrel.gov (c) use of very low-cost starting materials (e.g., low-purity salts or solvents), based on automatic purification of the deposited materials during plating; (d) a large-area, continuous, multi-component, low-temperature deposition method; (e) deposition of films on a variety of shapes and forms (wires, tapes, coils, and cylinders); (f) controlled deposition rates and effective material use (as high as 98\%); and $(\mathrm{g})$ minimum waste generation (i.e., the solution can be recycled) [28].

Most of the electrodeposited CZTSS precursor films reported are prepared from aqueous electrolyte solutions. The electrodeposition of an element (e. g., Sn) that has a standard reduction potential more negative than the water reduction potential becomes very difficult due to the competition between electroplating the desired element and water electrolysis. To avoid the water reduction issue, electrodeposition needs to be done using non-aqueous solvents with a large electrochemical window, like ionic liquids (ILs).

In this study, CZTSS thin films have been prepared by electrodeposition of multilayered $\mathrm{Cu}-\mathrm{Sn}-\mathrm{Zn}$ metal films on $\mathrm{Mo} / \mathrm{glass}$ substrates. $\mathrm{Cu}$ and $\mathrm{Zn}$ thin films were prepared from aqueous solution and $\mathrm{Sn}$ was prepared from ionic liquid solvent. The electrodeposited thin-film precursor films were subsequently annealed in a tube furnace in an elemental sulfur and selenium environment.

\section{EXPERIMENTAL PROCEDURE:}

In general, electrodeposition of $\mathrm{Cu}-\mathrm{Sn}-\mathrm{Zn}$ was performed sequentially from a Cu-plating solution, Sn-plating solution, and $\mathrm{Zn}$-plating solution, respectively. First, a Cu layer was electrodeposited on a Mo/glass substrate from an aqueous $\mathrm{Cu}$-plating solution [28], the second Sn layer was electrodeposited from an ionic liquid Sn-plating solution, and the third $\mathrm{Zn}$ layer was electrodeposited from an aqueous Zn-plating solution. The ionic liquid solution was prepared by dissolving $313 \mathrm{gm}$ choline chloride in $500 \mathrm{ml}$ ethylene glycol. Fisher Scientific (FB300) and VWR (300V) power supplies were used to electrodeposit $\mathrm{Cu}-\mathrm{Sn}-\mathrm{Zn}$ thin films. All films were electrodeposited by applying constant current. 
$\mathrm{Cu}$ was plated at $-6.5 \mathrm{~mA} / \mathrm{cm}^{2}$ for 3 minutes, $\mathrm{Sn}$ was plated at $-0.45 \mathrm{~mA} / \mathrm{cm}^{2}$ for 30 minutes and $\mathrm{Zn}$ was plated at -1.8 $\mathrm{mA} / \mathrm{cm}^{2}$ for 4 minutes. The desired film composition can be obtained by adjusting the film thickness of $\mathrm{Cu}, \mathrm{Sn}$ and $\mathrm{Zn}$. The films were electrodeposited in a vertical cell in which the electrodes (both working and counter) were suspended vertically from the top of the cell. Precursor films were prepared by employing a two-electrode cell in which the counter electrode was Pt gauze and the working electrode (substrate) was glass/Mo. The Mo film was about $1 \mu \mathrm{m}$ thick and was deposited by direct current (dc) sputtering. All chemicals were of Analar- or Puratronic-grade purity and were used as received. The precursor electrodeposited $\mathrm{Cu} / \mathrm{Sn} / \mathrm{Zn}$ stacked layers were annealed in a tube furnace at $570^{\circ} \mathrm{C}$ in the presence of $2 \mathrm{gm} \mathrm{Se}$ and $0.5 \mathrm{gm} \mathrm{S}$ for 60 minutes. The film compositions were analyzed using Agilent Technologies 7700 Series ICP-MS system. PV devices were completed by chemical-bath deposition of about $50 \mathrm{~nm} \mathrm{CdS}$, followed by radio frequency (RF) sputtering of $50 \mathrm{~nm}$ of intrinsic $\mathrm{ZnO}$ and $350 \mathrm{~nm}$ of $\mathrm{Al}_{2} \mathrm{O}_{3}$-doped conducting $\mathrm{ZnO}$. Bilayer Ni/Al top contacts were deposited in an e-beam system. The final step in the fabrication sequence was the deposition of an antireflection coating (100 $\mathrm{nm}$ of $\left.\mathrm{MgF}_{2}\right)$.

\section{RESULTS AND DISCUSSION}

Cyclic voltammograms (CVs) were obtained at $53^{\circ} \mathrm{C}$ with a scan rate of $50 \mathrm{mV} / \mathrm{s}$, using a 3-electrode system potentiostat (Princeton, VCM-4). The electrodes used for CV measurements were Pt-working, Pt-counter, and Pt-quasi reference electrodes [29]. The measurements were performed after the open circuit voltage of the electrochemical cell was stabilized (usually 1 hour). Fig. (1a) shows a CV curve of the choline chloride-based ionic liquid used in this study. The water reduction peak at $\mathrm{V} \approx 0.9 \mathrm{~V} v s \mathrm{Pt}$, indicates a trace amount of water present in the ionic liquid solvent. Fig. (1b) shows the $\mathrm{CV}$ curve of $0.1 \mathrm{M} \mathrm{SnCl}_{2} \cdot \mathrm{H}_{2} \mathrm{O}$ in choline chloridebased ionic liquid solution. The $\mathrm{CV}$ curve shows reduction $\left(\mathrm{Sn}^{2+}+2 \mathrm{e}^{-} \Rightarrow \mathrm{Sn}\right)$ peak of $\mathrm{Sn}$ at $-0.89 \mathrm{~V}$ in ionic liquid solvent when a Pt-quasi reference electrode is used. The standard reduction potential of $\mathrm{Sn}(\mathrm{II})\left[\mathrm{Sn}^{2+}+2 \mathrm{e}^{-}=>\mathrm{Sn}\right]$ is $-0.14 \mathrm{~V} v$ s. SHE in $1 \mathrm{M}$ aqueous solution at $25^{\circ} \mathrm{C}$ [30].

The precursor film composition as analyzed by ICP-MS was $\mathrm{Cu}_{2} \mathrm{Zn}_{1.57} \mathrm{Sn}_{0.99}$. The composition of the annealed film analyzed by ICP-MS was $\mathrm{Cu}_{2} \mathrm{Zn}_{1.89} \mathrm{Sn}_{0.94} \mathrm{Se}_{1.95} \mathrm{~S}_{1.41}$. The compositions of the films were normalized to $\mathrm{Cu}=2$. The compositions of the precursor and processed films were not ideal for high efficiency devices. The annealed film was $\mathrm{Zn}$ rich which could lead to the formation of $\mathrm{ZnS}$ and $\mathrm{ZnSe}$ impurity phases. Fig. (2) shows the X-ray diffraction (XRD) patterns of the absorber layer (annealed in Se and S). The measured peaks correspond to kesterite CZTS structure [joint committee on powder diffraction standards (JCPDS) \# 26-0575]. The molybdenum (Mo) substrate peak is labeled as Mo (110). The XRD diffraction analysis does not show $\mathrm{ZnS} / \mathrm{ZnSe}$ phases, even though the film is Zn-rich. The surface morphology and cross-sectional view (SEM) of the annealed film are shown in Fig. (3a, b) respectively. The SEM as shown in Fig. (3a, b), indicate that films are crackfree and have a compact dense morphology. The surface morphology (Fig. 3a) indicates secondary phases on melted large grain CZTSS thin film. The cross-sectional view (a)

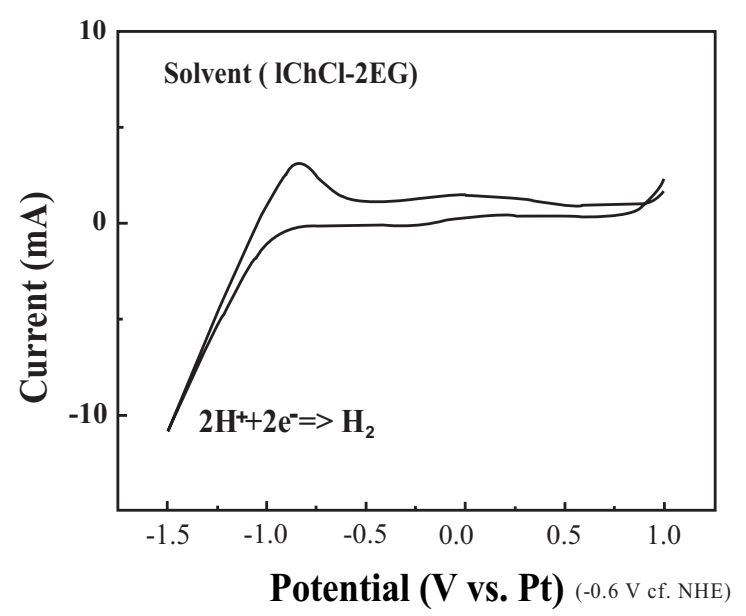

(b)

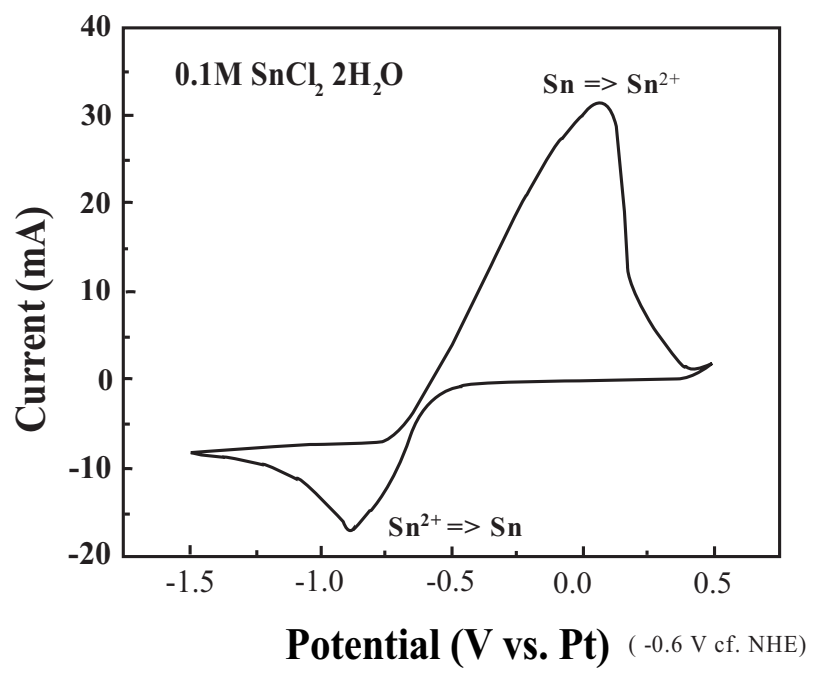

Fig. (1). (a) Cyclic Voltammogram (CV) of the ionic liquid and (b) $\mathrm{CV}$ of $0.1 \mathrm{M} \mathrm{SnCl}_{2}$ in ionic liquid. All $\mathrm{CVs}$ were performed at $53^{\circ} \mathrm{C}$.

(Fig. 3b) of the film shows the film thickness is about $3 \mu \mathrm{m}$ and it has a very rough surface morphology. The grain size estimated from the top-view and cross-sectional images ranged from about 1 to $2 \mu \mathrm{m}$ and the grains exhibit sharp facets. The compositional depth profile of the annealed film was analyzed using an Auger electron spectroscopy (AES). The profiles of the annealed film (Fig. 4) also show high concentration of $\mathrm{Zn}$ in the film. AES analysis data does not show any oxygen or other impurities in the film. Solar cell devices were fabricated from these absorber materials. The device efficiency of the electrodeposited CZTSS thin film without $\mathrm{MgF}_{2}$ (Fig. 5a) was $3.4 \%$ with a $\mathrm{V}_{\mathrm{oc}}=0.53 \mathrm{~V}, \mathrm{~J}_{\mathrm{sc}}=$ $16.1 \mathrm{~mA} / \mathrm{cm}^{2}$ and fill factor $=40$. The device efficiency with $\mathrm{MgF}_{2}$ (Fig. 5a) was $3.6 \%$ with a $\mathrm{V}_{\mathrm{oc}}=0.54 \mathrm{~V}, \mathrm{~J}_{\mathrm{sc}}=16.9$ $\mathrm{mA} / \mathrm{cm}^{2}$ and fill factor $=40$. Very poor fill factor and $J_{\mathrm{sc}}$ are probably due to poor film morphology and presence of secondary phases. Fig. (5b) displays the absolute external quantum efficiency $(\mathrm{QE})$ spectrum of the device. The 
maximum quantum efficiency is as high as $70 \%$ at $610-750$ $\mathrm{nm}$. This QE spectrum also reveals that the optical band gap of the CZTSS thin film is $\sim 1.33 \mathrm{eV}$.

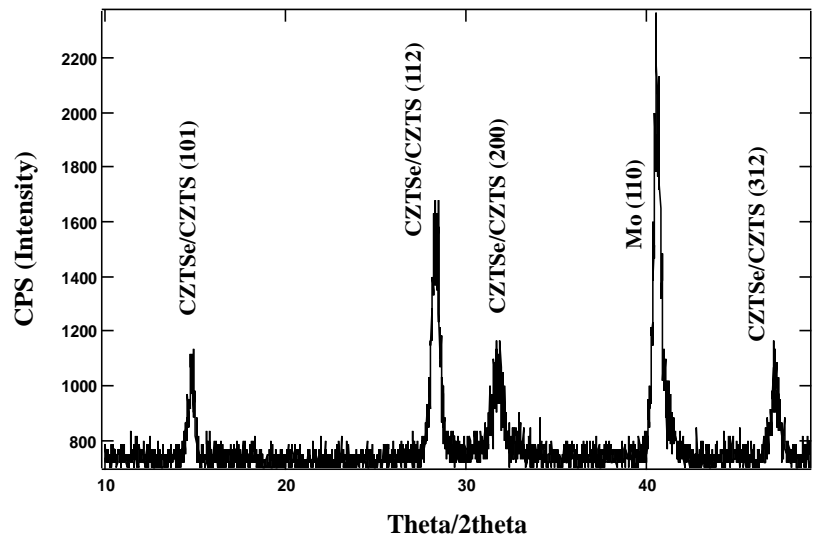

Fig. (2). X-ray diffraction (XRD) pattern of annealed CZTSS thin film (identified as kesterite, JCPDS 26-0575).

(a)

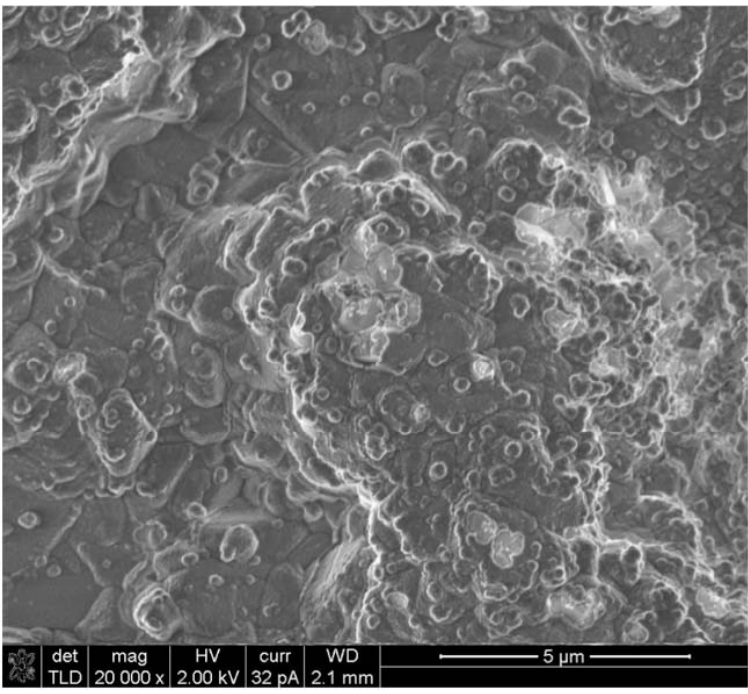

(b)

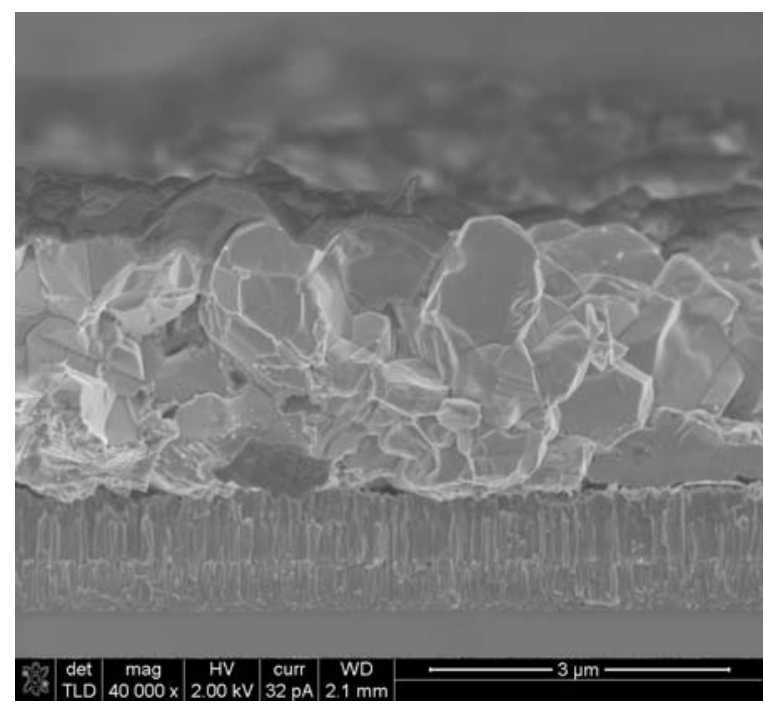

Fig. (3). (a) SEM surface morphology; (b) SEM cross-section of annealed CZTSS thin films.

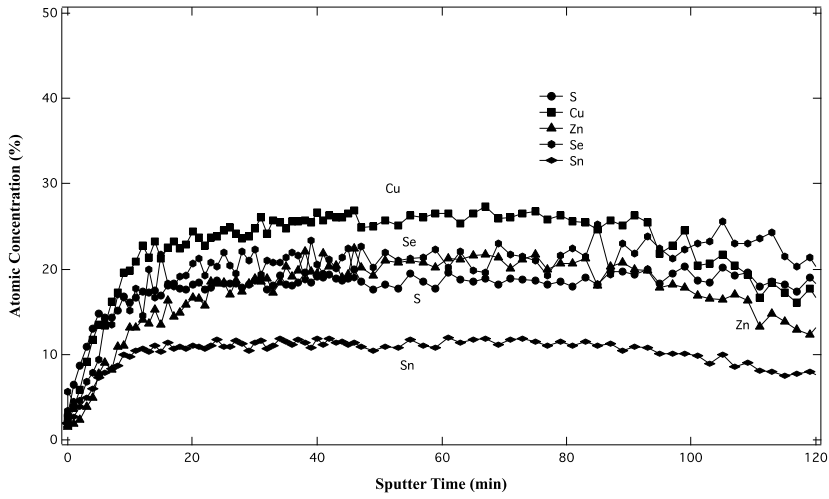

Fig. (4). Auger analysis data of the annealed electrodeposited CZTSS thin film.

(a)

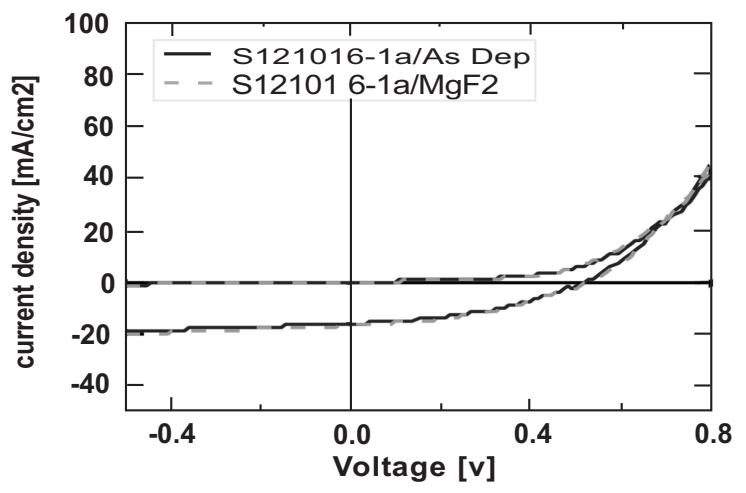

(b)

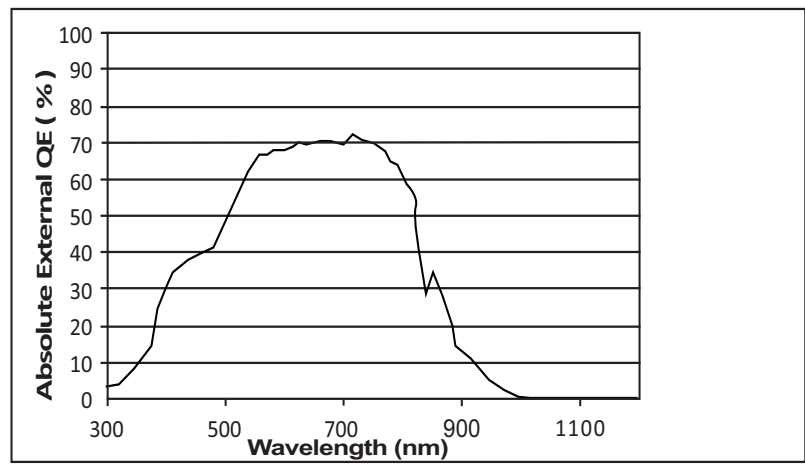

Fig. (5). (a) Current-voltage characteristics: $\mathrm{V}_{\mathrm{oc}}=0.53 \mathrm{~V}, \mathrm{~J}_{\mathrm{sc}}=16.1$ $\mathrm{mA} / \mathrm{cm}^{2}$, fill factor $=40 \%$, and efficiency $=3.4 \%$ without $\mathrm{MgF}_{2}$; $\mathrm{V}_{\mathrm{oc}}=0.54 \mathrm{~V}, \mathrm{~J}_{\mathrm{sc}}=16.9 \mathrm{~mA} / \mathrm{cm}^{2}$, fill factor $=40 \%$, and efficiency $=$ $3.6 \%$ with $\mathrm{MgF}_{2}$; (b) $\mathrm{QE}$ characteristics of the device with $\mathrm{MgF}_{2}$.

\section{CONCLUSION}

Electrodeposited $\mathrm{Sn}$ layer was fabricated from nonaqueous ionic liquid solvent. Electrodeposited $\mathrm{Cu}$ and $\mathrm{Zn}$ layers were fabricated from aqueous solvent. The stacked $\mathrm{Cu} / \mathrm{Sn} / \mathrm{Zn}$ layers were annealed in the tube furnace in the presence of elemental sulfur and selenium to obtain CZTSS absorber layer. The absorber material used for the device fabrication is zinc rich film. It is interesting to note that $3.6 \%$-device was fabricated from such non-stoichiometric $\mathrm{Zn}$-rich thin. This is a very encouraging result. This indicates 
that high efficiency devices could be obtained by hybrid electrodeposition process using both aqueous and ionic liquid solvents. At present the composition of the precursor films and processing conditions are being optimized to obtain smooth and uniform $\mathrm{Cu}_{2} \mathrm{ZnSn}(\mathrm{SSe})_{4}$ thin film. We are expecting to improve the device efficiency significantly after optimizing the deposition and processing conditions.

\section{CONFLICT OF INTEREST}

The authors confirm that this article content has no conflict of interest.

\section{ACKNOWLEDGEMENTS}

The authors thank Clay DeHart (NCPV, NREL) for device fabrication, Bobby To for SEM and Joel Pankow for AES analysis. This work has been performed by an employee of the Alliance for Sustainable Energy, LLC, under contract number DE-AC36-08GO28308 with the U.S. Department of Energy (LDRD program). The United States Government retains a nonexclusive, paid-up, irrevocable, worldwide license to publish or reproduce the published form of this work, or allow others to do so, for United States Government purposes.

\section{REFERENCES}

[1] Jimbo K, Kimura R, Kamimura $\mathrm{T}$, et al. $\mathrm{Cu}_{2} \mathrm{ZnSnS}_{4}$-type thin film solar cells using abundant materials. Thin Solid Films 2007; 515: 5997-9.

[2] Ito K, Nakazawa T. Electrical and optical properties of stannitetype quaternary semiconductor thin films. Jpn J Appl Phys 1998; 27: 2094-7.

[3] Chalapathy RBV, Jung GS, Ahn BT. Fabrication of $\mathrm{Cu}_{2} \mathrm{ZnSnS}_{4}$ films by sulfurization of $\mathrm{Cu} / \mathrm{ZnSn} / \mathrm{Cu}$ precursor layers in sulfur atmosphere for solar cells. Sol Energy Mater Sol Cells 2011; 95: 3216-21.

[4] Tanaka T, Nagatomo T, Kawasaki D, et al. Preparation of $\mathrm{Cu}_{2} \mathrm{ZnSnS}_{4}$ thin films by hybrid sputtering. J Phys Chem Solids 2005; 66: 1978-81.

[5] Seol JS, Lee SY, Lee JC, Nam HD, Kim KH. Electrical and optical properties of $\mathrm{Cu}_{2} \mathrm{ZnSnS}_{4}$ thin films prepared by rf- magnetron sputtering process. Sol Energy Mater Sol Cells 2003; 75: 155-62.

[6] Oishi K, Saito G, Ebina K, et al. Growth of $\mathrm{Cu}_{2} \mathrm{ZnSnS}_{4}$ thin films on $\mathrm{Si}$ (100) substrates by multisource evaporation. Thin Solid Films 2008; 517: 1449-52.

[7] Katagiri H, Sasaguchi N, Hando S, Hoshino S, Ohashi J, Yokota T. Preparation and evaluation of $\mathrm{Cu}_{2} \mathrm{ZnSnS}_{4}$ thin films by sulfurization of E-B evaporated precursors. Sol Energy Mater Sol Cells 1997; 49: 407-14.

[8] Katagiri H, Saitoh K, Washio T, Shinohara H, Kurumadani T, Miyajima S. Development of thin film solar cell based on $\mathrm{Cu}_{2} \mathrm{ZnSnS}_{4}$ thin films. Sol Energy Mater Sol Cells 2001; 65: 141-8.

[9] Grenet L, Bernardi S, Kohen D, et al. $\mathrm{Cu}_{2} \mathrm{ZnSn}\left(\mathrm{S}_{1-\mathrm{x}} \mathrm{Se}_{\mathrm{x}}\right)_{4}$ based solar cell produced by selenization of vacuum deposited precursors. Sol Energy Mater Sol Cells 2012; 101: 11-4.

[10] Wang K, Gunawan O, Todorov T, Shin B, Vhey SJ, Bojarczuk NA. Structural and elemental characterization of high efficiency $\mathrm{Cu}_{2} \mathrm{ZnSnS}_{4}$ solar cells. Appl Phys Lett 2011; 98: 051912.
[11] Salome PMP, Malaquias J, Fernandes PA, et al. Growth and characterization of $\mathrm{Cu}_{2} \mathrm{ZnSn}(\mathrm{S}, \mathrm{Se})_{4}$ thin films for solar cells. Sol Energy Mater Sol Cells 2012; 101: 147-53.

[12] Mitzi DB, Gunawan O, Todorov TK, Wang K, Guha S. The path towards a high-performance solution-processed kesterite solar cell. Sol Energy Mater Sol Cells 2011; 95: 1421-36.

[13] Todorov TK, Reuter KB, Mitzi DB. High-Efficiency Solar Cell with Earth-Abundant Liquid-Processed Absorber. Adv Mater 2010; 22: E156-9.

[14] Barkhouse DAR, Gunawan O, Gokmen T, Todorov TK, Mitzi DB. Device characteristics of a $10.1 \%$ hydrazine-processed $\mathrm{Cu}_{2} \mathrm{ZnSnS}_{4}$ solar cell. Prog Photovoltaics Res Appl 2012; 20: 6-11.

[15] Shin B, Zhu Y, Gunawan O, Bojarczuk NA, Chey SJ, Guha S. Thin film solar cell with $8.4 \%$ power conversion efficiency using anearth-abundant $\mathrm{Cu}_{2} \mathrm{ZnSnS}_{4}$ absorber. Prog Photovolt: Res Appl 2011; doi: 10.1002/pip.1174.

[16] Moriya K, Tanaka K, Uchiki H. Characterization of $\mathrm{Cu}_{2} \mathrm{ZnSnS}_{4}$ thin films prepared by photo-chemical deposition. Jpn J Appl Phys 2005; 44: 715-7.

[17] Zhou ZH, Wang Y, Xu D, Zhang Y. Fabrication of $\mathrm{Cu}_{2} \mathrm{ZnSnS}_{4}$ screen printed layers for solar cells. Sol Energy Mater Sol Cells 2010; 94: 2042-5.

[18] Tanaka K, Oonuki M, Moritake N, Uchiki H. $\mathrm{Cu}_{2} \mathrm{ZnSnS}_{4}$ thin film solar cells prepared by non-vacuum processing. Sol Energy Mater Sol Cells 2009; 93: 583-7.

[19] Araki H, Kubo Y, Jimbo K, et al. Preparation of $\mathrm{Cu}_{2} \mathrm{ZnSnS}_{4}$ thin films by sulfurization of co-electroplated $\mathrm{Cu}-\mathrm{Zn}-\mathrm{Sn}$ precursors. Phys Status Solidi C 2009; 61: 1266-8.

[20] Kurihara M, Berg D, Fisher J, Siebentritt S, Dale PJ. Kesterite absorber layer uniformity from electrodeposited precursors. Phys Status Solidi C 2009; 6: 1241-4.

[21] Ennaoui A, Lux-Steiner M, Abou-Ras D, et al. $\mathrm{Cu}_{2} \mathrm{ZnSnS}_{4}$ thin film solar cells from electroplated precursors: Novel low-cost perspective. Thin Solid Films 2009; 517: 2511-4.

[22] Pawar SM, Pawar BS, Moholkar AV, et al. Single step electro synthesis of $\mathrm{Cu}_{2} \mathrm{ZnSnS}_{4}$ (CZTS) thin films for solar cell application. Electro Chim Acta 2010; 55: 4057-61.

[23] Chan CP, Lam H, Surya C. Preparation of $\mathrm{Cu}_{2} \mathrm{ZnSnS}_{4}$ films by electrodeposition using ionic liquids. Sol Energy Mater Sol Cells 2010; 94: 207-11.

[24] Schurr R, Holzing A, Jost S, et al. The crystallization of $\mathrm{Cu}_{2} \mathrm{ZnSnS}_{4}$ thin film solar cell absorbers from co-electroplated $\mathrm{Cu}-$ Zn-Sn precursors. Thin Solid Film 2009; 517: 2465-8.

[25] Deligianni H, Ahmed S, Romankiw LT. The Next Frontier: Electrodeposition for Solar Cell Fabrication. Interface 2011; 20: 47-53.

[26] Ahmed S, Reuter KB, Gunawan O, Gao L, Romankiw LT, Deligianni $\mathrm{H}$. A high efficiency electrodeposited $\mathrm{Cu}_{2} \mathrm{ZnSnS}_{4}$ solar cell. Adv Energy Mater 2012; 2: 253-9.

[27] Todorov TK, Bag S, Gunawan O, Gokmen T, Zhu Y, Mtzi DB. Beyond $11 \%$ efficiency: characteristics of state-of-the-art $\mathrm{Cu}_{2} \mathrm{ZnSn}$

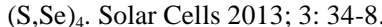

[28] Bhattacharya RN. CIGS-based solar cells prepared from electrodeposited stacked $\mathrm{Cu} / \mathrm{In} / \mathrm{Ga}$ layers. Sol Energy Mater Sol Cells 2013; 113: 96-9.

[29] Bhattacharya RN, Kim YJ. Cu-Zn-Sn-S thin films from electrodeposited metallic precursor layers. Open Surface Sci J 2012; 4: 19-24.

[30] CRC Handbook of Chemistry and Physics. In: David R, Ed. 74th ed. Boca Raton: CRC Press 1993-1994. 